\title{
The Importance of Maritime English Proficiency in Others Marine Related Undergraduate Programs
}

\author{
Tan Chiew Sia ${ }^{1, a, *}$, and Mohd Hafizi Said ${ }^{1, b}$ \\ ${ }^{1}$ School of Ocean Engineering, University Malaysia Terengganu (UMT), Kuala Terengganu, \\ Terengganu \\ a.tanchiewsia94@gmail.com, b.hafizi@umt.edu.my \\ *corresponding author
}

Keywords: Maritime English, Maritime Education and Training, Framework for Maritime English Proficiency, Undergraduate Program

Abstract: Maritime English proficiency standard is mandatorily used by all maritime based professionals and become an important tool to ensure safety where it is not only at sea but including shore, port and any maritime based industry. This study sought to determine the level of Maritime English proficiency among the other marine related undergraduate programs in University Malaysia Terengganu. Maritime English subject is a core subject for Nautical Science and Maritime Management Programme but not for other marine related undergraduate programs such as Maritime Technology, Maritime Informatics Technology, Marine Biology, Science Marine and Science Fisheries at University of Malaysia Terengganu (UMT). The importance for students to have sufficient proficiency in Maritime English as it's useful for them to use the accurate Maritime English terminology for journal and thesis writing and to practice correct communication and pronunciation of Maritime English. Data were obtained by conducting a series of interview with 90 students from Marine Science, Maritime Technology and Maritime Informatics Technology programme. The thematic content analysis was used to analyse data during interview session. Based on the findings, $46.1 \%$ of Maritime Technology students were considered achieved the level of proficiency in using maritime English terminologies. These results have shown that the important of offering Maritime English Subject to other marine related program.

\section{Introduction}

English is well known as international language that should be used worldwide and in any type of maritime communication. The necessity for the establishment of Maritime English (ME) resources and materials has been discussed in many conferences as well as a number of projects on Maritime Education and Training (MET). Renowned researchers such as [1] and [2] are among researcher that has shown interest in improving the level of Maritime English in shipping industry. However, the focus of these studies lies on the development of vocational and academic language courses which is aimed at the standard competence in the use of Maritime English for other related program as UMT is one of maritime focused Institution in the Malaysia. There are only a few studies has been 
discovered on the language competence and skills that Maritime Universities students need to acquire in order to deal successfully in their academic studies as well as with the challenge for potential shores side career path. Therefore, this study should become an important and knowledgeable platform for maritime students to use proper and correct maritime terminology in academicals writing and any maritime communication in shipping sector.

\subsection{Problem Statement of the Research}

Nowadays maritime schools are faced with the biggest challenge for developing mariner with high standards of competence and professionalism with a good English communication skill [3]. University Malaysia Terengganu (UMT) as one of the maritime universities in Malaysia that able to provide mariners where it is important to ensure UMT does not face the same challenge. The level of proficiency of Maritime English among the students is important to be classified as to ensure adequate usage of Maritime English in any maritime communication. Besides, the wrong terminology used in Maritime English needed to be analysed as it is beneficial in academicals and thesis writing for students. The usage of correct of Maritime English must be ensured the best way to help others related marine undergraduate students in UMT for becoming a competence graduate with high proficiency and knowledge in Maritime English.

\section{Literature Review}

According to the legislation, English in the shipping industry is known as Maritime English and the teaching of the subject at all maritime universities, institutes and colleges worldwide are governed by the IMO Model Course 3.17 (Maritime English). Consequently, this world-class standard document for the training has set a standard for the English language to be taught and mastered so as to comply with the regulation in maritime sector [4].

In maritime industry, English is considered as main tool for communication at sea and port. It acts as an important tool because given the international character of the maritime industry. On maritime job requirement has strongly emphasized the importance of English language proficiency in relation to shipboard operations and coastal areas. Companies employing non-native English employee have an obligation to ensure that effective English language country is available especially as members of the crew are now required to demonstrate knowledge of English adequate for professional and safety purposes at sea and shore areas. So, it is for ensuring to have a broad knowledge of English and good communication skills to be able to respond as the situation demands [5].

Besides, ship owners and shipping companies often seem to overlook basic issues like the training of the workers. Employing seamen from different nationalities brings different standards of training on board ship, both for what Maritime English is concerned in terms of SMCP, and for the level of knowledge regarding STCW, SOLAS, MARPOL and others. Along with this, cultural attributes which are brought by these seamen give a more complex extent to the use of the Maritime Language in any maritime sector [6]. Therefore, seafarer's ability to communicate to an acceptable standard of English is very essential and important in nowadays industry especially on maritime industry. Moreover, the increment on the number of casualty is caused by the poor level of communication skills of the employee [7]. It has increased the concern to all categories in maritime industry including the seafarers, ship owners, shipping company and maritime institution all over the country.

The focus of these studies focus on the standard competence in the use of Maritime English for a proper academic writing thesis any the importance for any maritime communication. So they mainly concern about maritime students and their needs for a common language, which is essential for avoiding used of wrong maritime terminology. There are only a few studies have been done on the language competence and skills that Maritime University students need to acquire in order to deal 
successfully with their academic studies as well as with the challenges of a potential shore side career path [8].

Nowadays it is well known all around the shipping industry that English is the main and only language that should be used in any type of maritime communication. The English language is the lingua franca of the maritime industry. In shipping industry, the Standard Marine Communication Phrases (SMCP) is used primarily for standardization of communication in the ship to ship and ship to shore communication [9].

Lastly, the lecturers from Maritime Universities all over the world should be better in explaining the students about the importance of competence and fluent in Maritime English. It is worth to note that the students as a new learner of a language (English language) really do need to build a solid foundation of knowledge. It is beneficial for them if their lecturer had well experience for teaching Maritime English. It can help them to improve by using some important maritime terms used daily in shipping industry and for any type of communications in the maritime sector [10].

\section{Methodology}

\subsection{First Step of Data Analysis}

The first step is intended to determine the level of proficiency of maritime English among other marine related undergraduate. There were a few series semi-structured interviews and questionnaire required to be answered by the students where it mainly aimed for explaining and possibly adding to the data findings. Respondents of the study were 90 students from the maritime technology (30 students), marine science (30 students) and maritime informatics technology (30 students) program. The primary data were collected by the relevant literature and also encouraged discussion about issues that the interviewees considered relevant. To facilitate this process, an interview guide was developed that identified introductory stage which require students to answer spontaneously in recognizing the basic operations of the vessel and ship terminologies. The Basic Marine Vocabulary (BMV) includes:

- Parts of ship

- Types of ship

- Names and functions of equipment on board of ship and port equipment

- Routine operations on board such as bunkering, alongside, maintenance, loading and unloading of cargo, watch-keeping, mustering and etc.

- Ship movement and directions

- Basic ship communication in English

- Ship organization

- Duties and responsibilities of board

\subsection{Second Step of Data Analysis}

The second step is for analysing the wrong terminology of Maritime English used by the related undergraduate students. By using the same sample as previous step the secondary data were used by analysing the final year thesis paper for other related marine undergraduate. The final year thesis writing was selected accordingly to the courses of Maritime Technology, Maritime Informatics Technology and Marine Biology. The common mistake made by the students by using Maritime English terms was determined. Conventional Content Analysis was used to analyse the data where coding categories are derived directly from the text data used to provide results for the second step. Content analysis is a research technique used to make replicable and valid inferences by interpreting and coding textual material. A summative content analysis involves counting and comparisons, 
usually of keywords or content, followed by the interpretation of the underlying context [11]. In this research, the conventional content analysis is used to determine common mistake in Maritime English terms.

\subsection{Third Step of Data Analysis}

The last step is to suggest ways to improve Maritime English among other marine related undergraduate. Interview sessions were held with a few selected experts. The experts were divided into two categories which are former mariners and academicians. They were chosen from the School of Ocean Engineering as they are more expertise for the purpose of the research. The opinions and suggestions on ways to improve Maritime English proficiency among other related marine undergraduate that been achieved during the interview session were collected as primary data. The content analysis was used to analyse the data from interview session. This is probably the most common method used in qualitative research. It aims to find common patterns across a data set. This method follows a few steps:

- Getting familiar with the data (reading and re-reading).

- Coding by label the whole text.

- Searching for themes with broader patterns of meaning.

- Reviewing themes to make sure they fit the data.

- Defining and naming themes.

- The write-up (creating a coherent narrative that includes quotes from the interviewees)

\section{Results and Discussion}

The English Proficiency level of undergraduate students based on the Basic Marine Vocabulary (BMV) interview was carried out. The total undergraduate student for a sample of this research was 90 students. The respondents are required to answer a set of questionnaires prepared by the researcher. The questionnaire consists of 20 questions about Basic Marine Vocabulary (BMV). The results show that students are incompetent in basic ship communication in English and use wrong terminology of basic Maritime English with the mean achievement of the percentage 46.1\% (30 undergraduate students) from Maritime Technology program, 32.2\% (30 undergraduate students) from Maritime Informatics Technology program and 14.2\% (30 undergraduate students) from Marine Science program. The table 1 below showed the mean percentage of respondents from Marine Technology students, Maritime Informatics Technology students and Marine Science students.

Table 1: The Percentage of Respondent by Undergraduate Students

\begin{tabular}{|c|c|c|c|}
\hline $\begin{array}{c}\text { No of } \\
\text { Students }\end{array}$ & $\begin{array}{c}\text { Maritime } \\
\text { Technology }\end{array}$ & $\begin{array}{c}\text { Maritime } \\
\text { Informatics } \\
\text { Technology }\end{array}$ & $\begin{array}{c}\text { Marine } \\
\text { Science }\end{array}$ \\
\hline 1 & 50 & 20 & 15 \\
\hline 2 & 45 & 25 & 20 \\
\hline 3 & 55 & 35 & 20 \\
\hline 4 & 30 & 30 & 15 \\
\hline 5 & 40 & 40 & 10 \\
\hline 6 & 40 & 35 & 10 \\
\hline 7 & 45 & 35 & 5 \\
\hline 8 & 20 & 20 & 5 \\
\hline 9 & 40 & 15 & 15 \\
\hline
\end{tabular}




\begin{tabular}{|c|c|c|c|}
\hline 10 & 65 & 40 & 10 \\
\hline 11 & 60 & 45 & 30 \\
\hline 12 & 55 & 50 & 20 \\
\hline 13 & 55 & 50 & 10 \\
\hline 14 & 45 & 20 & 10 \\
\hline 15 & 50 & 20 & 15 \\
\hline 16 & 45 & 25 & 20 \\
\hline 17 & 55 & 35 & 20 \\
\hline 18 & 30 & 30 & 15 \\
\hline 19 & 40 & 40 & 10 \\
\hline 20 & 40 & 35 & 10 \\
\hline 21 & 45 & 35 & 5 \\
\hline 22 & 20 & 20 & 5 \\
\hline 23 & 40 & 15 & 15 \\
\hline 24 & 65 & 40 & 10 \\
\hline 25 & 60 & 45 & 30 \\
\hline 26 & 55 & 50 & 20 \\
\hline 27 & 55 & 50 & 10 \\
\hline 28 & 45 & 20 & 10 \\
\hline 29 & 50 & 20 & 15 \\
\hline 30 & 45 & 25 & 20 \\
\hline Total & 1385 & 965 & 425 \\
\hline Mean $(\%)$ & $1385 / 30=46.1$ & $965 / 30=32.2$ & $425 / 30=14.2$ \\
\hline
\end{tabular}

Maritime Technology students achieve the highest score compared to Maritime Informatics Technology and Marine Science as the students taking more subjects toward maritime subject in their syllabus. However, it is noticeable that during interview, most students are unable to answer and speak effectively as they do not know the necessary of the specific terminology of Maritime English or in other words they lack of knowledge about basic marine terminology for efficient maritime communication. The percentage of the mean scored is low and does not achieve the expected target by researcher. Therefore, UMT as one of the maritime institutes have to promote and offering the student to learn and study the subject more effectively and should become one of their compulsory subject for their syllabus.

Besides, there were many wrong terminology has been identified throughout the context analysis of the thesis writing. The patterns of their wrong terms used were random as there is no specific maritime subject for them to have adequate knowledge of using the correct terminology for thesis writing. This is important for UMT as one of the maritime focused institute to upgrade the Maritime English proficiency of the students in order to help them attain the required writing and communication skills while in the performance of their duties and responsibilities in academics. In this research, the results are shown in the simplest way to ensure the students realize their mistakes made. The feedback from the students after the research had been complete is highly appreciated as the researcher able to help to the undergraduate students in identifying the common mistake in using specific Maritime English terminology. The table 2 as below shown the wrong terminology frequently used by the undergraduate students. 
Table 2: The Wrong Terminology Used

\begin{tabular}{|l|l|}
\hline \multicolumn{1}{|c|}{ WRONG TERM } & \multicolumn{1}{c|}{ CORRECT TERM } \\
\hline Ship's pointing & Ship's heading \\
\hline Map & Chart \\
\hline Leave the ship & Abandon ship \\
\hline Coordinate of the ship & Position of the ship \\
\hline Kitchen & Galley \\
\hline Floor & Deck \\
\hline Fall into the sea & Man overboard \\
\hline Firehouse & Lighthouse \\
\hline Ship's body & Ship's hull \\
\hline Rope breaking & Rope parting \\
\hline Parking & Alongside/Berthing \\
\hline Shore Manager & Port Authority \\
\hline Left/Right & Port/Starboard \\
\hline Street of Malacca & Straits of Malacca \\
\hline
\end{tabular}

Moreover, the results were discussed is based on the third step for recommendations to improve Maritime English proficiency among other related marine in UMT. The experts are divided into two categories which are former mariners and academicians. Therefore, the results of the interviews will also divide into two parts which are opinion and suggestion from former mariners and academicians. The results of interviews are explained below.

\subsection{Former Mariners}

i. Instructor for Maritime English subject - The lecturer that teaches Maritime English subject must be among former mariner as they have all professional competence and experience to teach Maritime English.

ii. Full English Language used in teaching ME - Maritime Universities need to upgrade the English proficiency of the students in order to help them attain the required communication skills while in the performance of their duties and responsibilities in this industry. The teaching of all maritime related subjects must be in full English Language even the students are a non-native speaker of English.

iii. Use of IMO SMCP during lecture - Standard Marine Communication Phrases (SMCP) by International Maritime Organization (IMO) must be used by all institution, lecturers or instructor of ME course as a guideline when teaching Maritime English or related subjects.

iv. Student's competence - General English helps students to cope easier with all situations they face while learning all related maritime subject. The students need to build a strong foundation in General English before mastering Maritime English.

\subsection{Academicians}

i. Importance of reading - Our brain is very smart and by regularly reading related material, a person can improve their new learnt language. Experts believe that by always reading, someone can improve rapidly in learning a new language.

ii. Lecturer's role in varying the method of teaching - Students easily get bored and lose their concentration as the lecturer still using old conventional way. By using latest technology, 
student's interest in learning will increase as it makes the learning process more fun and interactive and conducive.

iii. Surround yourself with native speaker - The environment is one of a factor that affects the student's proficiency in English. Students need can master English through socialize with native speaker English.

iv. Extend hours of learning English - The maritime institution must play the important roles to help students for emphasizing their English proficiency. Mastering General English is essential before further learning of Maritime English. The hours for English course must be extended to a suitable level to ensure students keep learning English. Thus, it will be easier for them to learn Maritime English.

\section{Conclusions}

The undergraduate of other marine related programme in UMT agreed on the importance of the improvement of Maritime English as one of the requirements in getting a lucrative job in the seaborne industry. They also realize about the importance of using the correct Maritime English terms also useful in their thesis or journal writing and preferable on improving it. Moreover, the school must take responsibilities for this subject matter and need to be recommended the Maritime English subject should including in other marine related undergraduate program for their syllabus. This issue must be solved expeditiously to ensure the students have great chance to learn proper Maritime English in the future.

\section{Acknowledgements}

The success and final outcome of this research required a lot of guidance. I am extremely privileged to have got this all along the completion of my research. I respect and thank to all lecturers from School of Ocean Engineering for providing me an opportunity to do the research and giving me all support and guidance, which made me complete the research duly. I am extremely thankful to them for providing a constant encouragement and guidance.

\section{References}

[1] Blakey, T, N, English for Maritime Studies: Prentice Hall, 2004

[2] Pritchard, B, On some issues in the standardization of Maritime English-Pedagogical Implications, In Proceedings of International Seminar on Maritime English, Istanbul Technical University, Istanbul, 20-22 March 2002

[3] Jomarie, D, Maritime Student's English Proficiency and Their Feedback on Instructional Materials, 2015

[4] Trenkner, P. Some Issues in the Standardization of Maritime English. Proceeding of International Seminar on Maritime English, pp. 5162, 2002

[5] Logie, Thinking globally, acting locally-Implementation of IMO Model Course 3.17: Maritime English”. Paper presented at the Eleventh IMLA international Workshop on Maritime English, Varna Bulgaria, 2010

[6] Apostol-mates, R., Barbu, A, Is Maritime English the key to solving communication problems within multinational crews, 2015

[7] Rashed, K. S., Kamal, A, Maritime English holds a great stake in both safety and security of merchant's vessel, 2010

[8] Kourieos, S., Investigating Maritime students' academic and professional language skills: A needs analysis, 20

[9] Rizal, S., A Preliminary Study On Standard Marine Communication Phrases (Smcp), 2015

[10] Popescu, C, Maritime English A Necessity for Nowadays Apprentices, 2011

[11] Mayring, P., Qualitative content analysis. Forum: Qualitative Social Research, 1(2), 2000 